\title{
Correction to: The safety of Covid-19 mRNA vaccines: a review
}

\author{
Pratibha Anand ${ }^{1 *}$ and Vincent P. Stahel ${ }^{2}$ \\ Correction to: Patient Saf Surg 15, 20 (2021) \\ https://doi.org/10.1186/s13037-021-00291-9
}

Following publication of the original article [1], it was noticed that the published version of this article has contained incorrect title. The correct title is "The safety of Covid-19 mRNA vaccines: a review". The original article has been corrected.

\section{Author details}

${ }^{1}$ University of Colorado (CU) School of Medicine, 13001 E 17th Place, Aurora, CO 80045, USA. ${ }^{2}$ University of Colorado (CU) Boulder Undergraduate,

Program, Boulder, CO 80309, USA.

Published online: 18 May 2021

\section{Reference}

1. Anand P, Stahel VP. Review the safety of Covid-19 mRNA vaccines: a review. Patient Saf Surg. 2021;15:20. https://doi.org/10.1186/s13037-021-00291-9.

The original article can be found online at https://doi.org/10.1186/s13037021-00291-9.

* Correspondence: pratibhastar@gmail.com

'University of Colorado (CU) School of Medicine, 13001 E 17th Place, Aurora, CO 80045, USA

Full list of author information is available at the end of the article

(c) The Author(s). 2021 Open Access This article is licensed under a Creative Commons Attribution 4.0 International License, which permits use, sharing, adaptation, distribution and reproduction in any medium or format, as long as you give appropriate credit to the original author(s) and the source, provide a link to the Creative Commons licence, and indicate if changes were made. The images or other third party material in this article are included in the article's Creative Commons licence, unless indicated otherwise in a credit line to the material. If material is not included in the article's Creative Commons licence and your intended use is not permitted by statutory regulation or exceeds the permitted use, you will need to obtain permission directly from the copyright holder. To view a copy of this licence, visit http://creativecommons.org/licenses/by/4.0/. The Creative Commons Public Domain Dedication waiver (http://creativecommons.org/publicdomain/zero/1.0/) applies to the data made available in this article, unless otherwise stated in a credit line to the data. 